Final article:

Lindgreen, A., Córdoba, J.-R., Maon, F., and Mendoza Guerra, J.M. (2010), "Making sense of social strategies in Latin America", Journal of Business Ethics, Vol. 91, Suppl. 2, pp. 229242. (ISSN 0167-4544)

For full article, please contact LindgreenA@cardiff.ac.uk

\author{
Adam Lindgreen, University of Birmingham \& IESEG School of Management ${ }^{1}$ \\ José-Rodrigo Córdoba, Royal Holloway, University of London ${ }^{2}$ \\ François Maon, Université catholique de Louvain ${ }^{3}$ \\ José María Mendoza, Universidad del Norte, Colombia ${ }^{4}$
}

\footnotetext{
${ }^{1}$ For all correspondence: Dr. Adam Lindgreen, Professor of Marketing at University of Birmingham \& Affiliated Professor of Marketing at IESEG School of Management. Correspondence address: Professor Adam Lindgreen, University of Birmingham, Edgbaston, Birmingham B15 2TT, the U.K. E-mail: Adam_Lindgreen@hotmail.com.

${ }^{2}$ Dr. José-Rodrigo Córdoba School of Management, Royal Holloway, University of London, Egham, Surrey TW20 0EX, the United Kingdom. E-mail: J.R.Cordoba-Pachon@rhul.ac.uk.

${ }^{3}$ Dr. François Maon, Department of Marketing, Louvain School of Management, Université catholique de Louvain, Place des Doyens 1, 1348 Louvain-la-Neuve, Belgium. E-mail: maon@mark.ucl.ac.be.

4 Dr. José María Mendoza, School of Business, Universidad del Norte, Km.5 Vía Puerto Colombia, Barranquilla, Colombia. E-mail: mjmendoza@uninorte.edu.co.
} 


\title{
CORPORATE SOCIAL RESPONSIBILITY IN COLOMBIA: \\ MAKING SENSE OF SOCIAL STRATEGIES
}

\begin{abstract}
As corporate social responsibility (CSR) grows increasingly well known and accepted worldwide, organizations attempt to make sense of their social strategies and bridge the gap between their current situation and what their stakeholders expect of them. If social strategies represent a potential stepping stone to more sophisticated forms of CSR, then research must investigate the strategies that organizations have adopted. After defining a framework for classifying and analyzing organizations' social strategies, this article considers empirical evidence from ten case studies in Colombia to reveal how organizations might build on their social involvement to engage in more sophisticated CSR practices. The framework also suggests some different trajectories that organizations might follow.
\end{abstract}

KEYWORDS: corporate social responsibility (CSR); social strategies; Colombia. 


\section{CORPORATE SOCIAL RESPONSIBILITY IN COLOMBIA: \\ MAKING SENSE OF SOCIAL STRATEGIES}

As organizations continue to assume greater levels of social responsibility, especially in the past decade, corporate social responsibility (CSR) has gone beyond being just a buzzword (Bhattacharya and Sen, 2004; Lichtenstein, Drumwright, and Braig, 2004; McWilliams, Siegel, and Wright, 2006). The basic premise in CSR literature, still largely dominated by U.S. and European perspectives, is that organizations cannot be concerned solely with making a profit but also must engage in "actions that appear to further some social good, beyond the interests of the firm and that which is required by law" (McWilliams, Siegel, and Wright, 2006: 1). In practice, organizations attempt to develop social strategies that will enable them to bridge the gap between their current situation and the expectations of stakeholders (Crane, Matten, and Moon, 2008; Crane, Matten, and Spence, 2007; Dunphy, Griffiths, and Benn, 2003; Kotler and Lee, 2005).

Yet it remains difficult to provide a single definition of CSR (Carroll, 1999; Garriga and Melé, 2004; Lee, 2008), because the term appears in a variety of forms (Andriof and McIntosh, 2001; Pinkston and Carroll, 1996; Snider, Hill, and Martin, 2003). This situation largely reflects the basic idea that CSR evolves over time; some (intermediary) CSR elements are not practices in their own right but instead constitute transition states (Egri and Ralston, 2008; Hawkins, 2006; Lindgreen, Swaen, and Johnston, 2007). Current research also cannot determine conclusively, for example, whether CSR develops progressively along a continuum or moves in multiple directions.

To extend this discussion, we identify the evolution of CSR practices with respect to the development of formalized structures inside an organization. We also study the pathdependent nature of CSR practices, such that prior divergences lead to different CSR 
practices in the future, and thereby examine the route that organizations follow in implementing their CSR practices.

Furthermore, the heavy influence of a U.S. perspective (Crane, Matten, and Spence, 2008) and increasingly a European one (Smith and Lenssen, 2009) has defined conceptualizations of CSR (Crane and Matten, 2007; Fox, 2004). Yet these conceptualizations and related recommendations for how organizations can act responsibly may be of limited utility in other cultural contexts (Lindgreen, Swaen, and Campbell, 2010). In particular, cultural aspects often determine what is required and expected of organizations with regard to economic, legal, ethical, and discretionary concerns (e.g., Burton, Farh, and Hegarty, 2000; Chapple and Moon, 2005; Kusku and Zarkada-Fraser, 2004; Matten and Moon, 2008; Visser, 2006).

Our study therefore investigates how Colombian organizations historically have engaged in CSR, to the extent that CSR has become a source of value to both organizations and wider society. We contribute to existing literature by examining the manifestation of CSR practices in a setting outside the United States or Europe. Corporate social responsibility already exists in Colombia, albeit not in the way and with the features described elsewhere, which suggests that CSR development in this country reflects the actions of stakeholders involved in social strategies rather than the imposition of practices from outside. This approach to making sense of CSR seems more inclusive and better reflects the actual social context of organizations, which may facilitate participative learning with communities to encourage CSR success (Gutierrez and Jones, 2004). For example, some studies pertaining to the evolution of CSR suggest continuous learning processes enable goals that are realistic for the organizational context (Zadek, 2007). We attempt to help determine why organizations across cultures may adopt CSR (Aguilera et al., 2007).

Third, we develop the idea of CSR as a continuum of practices, within which it is worth exploring what organizations and communities do, as well as how their efforts to develop 
strategic actions result in what might be called social strategies. We particularly focus on how organizations develop strategies that fit their social context and find meaningful ways to work with local communities by combining various elements of CSR practices identified in prior literature (Bedicks and Arruda, 2005; de Oliveira, 2006; Peinado-Vara, 2006; Schmidheiny, 2006). To integrate such elements, we analyze organizations' social strategies and suggest some ways forward for developments of CSR in the region that might adopt a more international - that is, U.S. or European - form while still tackling relevant local or national issues.

We structure the remainder of this article as follows: First, we review literature pertaining to CSR and how it has influenced the study of organizations in Latin America. This review leads to our theoretical framework. Second, we describe the methodology we use, and third, we present and discuss the results of our examination of 10 organizations and their CSR practices. Fourth, we identify our study's contributions and managerial implications, as well as some limitations, and suggest avenues for further research.

\section{Literature Review}

\section{Latin America as a region of extremes}

The history of Latin America features inequality, exclusion, paternalism, and corruption, but it also is marked by magical realism, in which anything seems possible; thus, it is a region of extremes. As Gabriel García Marquez, the Colombian author and winner of the 1982 Nobel Prize in Literature, once noted, "We are capable of the most audacious adventurous, but also of the most horrible crimes." Following this logic, organizations in Latin America often appear driven by contradictory objectives: becoming more competitive in the global arena while still coping with pressing issues such as underdeveloped physical infrastructure, little access to education, social and economic inequalities, political uncertainty, and increasing 
costs of living. In turn, managerial practices often do not encompass the "best practices" developed elsewhere (Dávila and Samper, 1994).

Extremes also pervade the current state of CSR in Colombia, as reflected in the ways in which many organizations operate in the region, which makes it "as difficult to generalize about corporate citizenship, or corporate social responsibility (CSR), in Latin America, as it is to generalize about anything in Latin America" (Schmidheiny, 2006: 21). Emerging CSR research in Latin America mostly features studies conducted by international organizations (Haslam, 2004; Vives, 2006) or academics who are interested in how different actors can promote CSR and/in the context of development (Gutierrez and Jones, 2004; Peinado-Vara, 2006; Prieto-Carron et al., 2006). These examples highlight the importance of codes of conduct, networks, alliances, and partnerships in developing and improving CSR initiatives and programs (Bedicks and Arruda, 2005; Haslam, 2004). In addition, the sustainability of CSR initiatives has become a more pertinent issue (de Oliveira, 2006), partly because of globalization (Schmidheiny, 2006). Many CSR initiatives in Latin America aim to meet particular sustainable criteria, which provide the reference to be followed by other organizations in the region (Ospina, 2005). Yet at the other extreme, we find alternative practices, initiatives, and programs that contain some features resembling CSR, often dealing with local social problems.

We therefore turn our attention to how organizations tackle their local contexts and make sense of them using what we call social strategies. To contextualize such strategies, we propose a referential continuum of CSR, ranging from no presence or responsibility (or a lack thereof, as manifested in the form of corruption) to an advanced degree of CSR that seems to entail the best (and internationally recognized) practices. Several studies of CSR in the region suggest that depending on their degree of CSR development, country-level initiatives on the American continent can be classified as follows (Haslam, 2004): running (Canada and the 
United States), catching up (developed countries such as Argentina, Chile, and Mexico), walking (rest of South America), and stalled (Central America and the Caribbean). As Figure 1 depicts, one extreme of the CSR continuum represents the absence of any practices, with little attention paid to issues of corruption, poverty, or corporate mismanagement (Gutierrez and Jones, 2004; Schmidheiny, 2006).

At the other extreme, which we call large-scale and developed CSR (Figure 1), we find integrated CSR and business strategies, together with local, national, and international systems that monitor CSR compliance through codes of conduct, governance, and sustainability. This end of the spectrum also acknowledges the inclusion of community groups in CSR efforts to engage with sustainable development issues. Such a community orientation appears to help organizations "obtain a social license to operate" (Egri and Ralston, 2008: 326). However, if the company is only involved in its community, it may generate questions about its genuine stakeholder involvement (Brammer and Millington, 2003), the effects of its CSR practices on the identities and values of others in the area, and the long-term impact of its practices, beyond improving its supply chains in the region (Schmidheiny, 2006). It therefore is necessary to identify appropriate ways for organizations to move forward, from what they could begin to do about CSR (or what they are already doing) to integrating CSR practices into their organizations (Maon, Lindgreen, and Swaen, 2008).

\section{[Insert Figure 1 Around Here]}

Because Latin America as a region represents a middle ground (between the extremes), it could help us understand how organizations attend to the needs of their social environment. Rather than simply accepting colonization by foreign practices (Ibarra-Colado, 2006), such as blind compliance with CSR codes, firms in this area should develop their CSR by observing what other organizations are doing and adapting the best practices. We echo Schmidheiny's 
(2006: 22) claim that "the key CSR challenges for the [Latin American] region, and the entire developing world, have to do not so much with the numbers of companies talking about CSR, but with creating a home-grown, meaningful form of CSR that addresses local issues and improves society." It is thus imperative to identify the seeds of CSR in the region, learn from their development and impacts, and engage in dialogue for the mutual benefit of organizations, both in the region and worldwide.

Drawing on existing strategy literature (Porter, 1980) and previous work on studying management practices in Colombia (Mendoza, 2006), we propose the term "social strategy" to refer to organizational activities aimed at generating positive impacts in a social environment. Social strategies can be an integral part of organizations' strategic planning processes. They often emerge as initiatives led by individual managers or company owners (mecenas) in response to the immediate needs of employers or community groups in certain geographical locations. Their motivations also may be external (e.g., international charity organizations) or reflect the mecenas' moral values, which can make it difficult to identify the exact historical origins. As a point of departure, we focus on identifying and studying such activities after they become corporate strategies - that is, after they have been allocated resources, monitored in their progress, and evaluated with regard to their ability to address the social needs of different stakeholders.

To understand the nature of social strategy in a Colombian context, we classify the types of social strategies on which organizations may draw. In Table 1, we depict two strategic dimensions that organizations might follow. First, a firm might base its strategy on the level of autonomy, that is, the degree to which it assumes responsibility solely (independent) or in conjunction with other organizations (leveraged) for defining and implementing strategies. Independence implies that organizations can create their own foundations to attend to the needs of various social groups. The scope of their strategies might be internal (i.e., 
employees), extend to the neighboring community, or move to a national level. Organizations could attend to various needs by providing differentiated products, valued for their content (e.g., education), or by imposing a minimum cost.

Second, a firm can base its strategy on the portfolio of products offered, such that it considers only existing products or diversifies its offerings to attend to the needs of the environment. A portfolio of products (specialized versus diversified) enables organizations to focus on a particular market that might address the needs of everybody (global), particular segments of the population (e.g., children, older consumers), or a particular niche (e.g., children from three to five years of age).

As Table 1 reveals, within these two dimensions, organizations can follow several types of strategies, which are distinguished by particular attributes. The classification provides an initial framework for assessing organizations' formulation and implementation of social strategies. In turn, we investigate managerial perceptions of the types of social strategies that they adopt to respond to the needs of their particular environment. Thus, we gain useful knowledge about organizations' current actions (not what they "should" be doing), with a view of understanding how they can integrate "external" CSR practices or requirements that might enrich their existing efforts. After interpreting organizations' social strategies in terms of their degree of CSR development, we discuss the implications of moving "forward" within the spectrum of practices depicted.

\section{[Insert Table 1 Around Here]}

\section{Methodology}

Qualitative methods are appropriate for studies of complex processes (Eisenhardt, 1989; Lindgreen, 2008; Yin, 1994). We adopt a multiple-case approach because of the complex nature of the phenomenon and our need to take into account a large number of aspects (Yin, 1994). Specifically, we employ Eisenhardt's (1989) multiple case study approach. Eisenhardt 
contends that the use of secondary data and multiple interviews in each case help develop rich insights and provide the basis for greater transferability of the findings to other contexts. We follow these recommendations in our study.

We select the cases according to a replication logic, such that each "case is considered akin to a single experiment" (Yin, 1994: 46). That is, each case "either (a) predicts similar results or (b) produces contrasting results but for predictable reasons" (Yin, 1994: 46). We also employ theoretical sampling to select additional cases (Strauss and Corbin, 1998). In total, we choose 12 cases for study; five replications are sufficient in studies of highly complex cases to improve certainty (Yin, 1994). The cases pertain to the following Colombian organizations, which are both for- and not-for-profit: Cementos del Caribe, Electricaribe, Electrocosta, Fedco, Fundación Corona, Fundación Mamonal, Fundación Mario Santo Domingo, Intercor, Monómeros Colombo-Venezolanos, and Promigas. These organizations all are involved in social responsibility; however, they exhibit differences in the details of their involvement, which helps us ensure our study achieves theoretical saturation (Lincoln and Guba, 1985). We list some details of the case organizations in Table 2.

\section{[Insert Table 2 Around Here]}

Prior to each interview with the organization, we reviewed publicly available secondary material and promotional information provided by each organization to increase our familiarity with the case; these materials included corporate plans and brochures, organizational Web sites, annual reports, and policy documents. We conducted interviews with respondents at each of the 10 organizations' head offices in Colombia. Interviews with three foundations (Corona, Mamonal, Mario Santo Domingo) and three companies (BASF, Dupont, Intercor) were carried out by assistants hired to perform the interviews. Each interview lasted approximately 1.5 hours on average (range: 1 to 2 hours). The interviews 
involved the CEO, CSR manager, or administrative vice-president of the organizations and the directors of the social foundation.

The interview questions focused on a descriptive history of the organizations' involvement in social settings, their motivations and drivers for being involved, strategies to deal specifically with their social responsibilities, pressures for and against social responsibilities, specific social programs and projects, the budget allocated to these projects, and the networks and alliances in which the organizations were involved. We began the interviews with broad questions that enabled the respondents to present the material on their own terms. Interspersed with subsequent general questions, we included specific prompts to gain greater insights into specific lines of inquiry, such as details about particular projects. Although we employed a short, standardized guide for each interview, the process also was driven by emerging topics noted in each interview and the unique aspects of each case. Interviewing ceased when we achieved saturation, that is, when additional interviews yielded few new insights (Strauss and Corbin, 1998). We outline the interview details in Table 3.

\section{[Insert Table 3 Around Here]}

Following the primary interviews, we examined additional information provided by the respondents and other sources, including government documents, mandated reports, industry conference proceedings, magazines, books, conference papers, and consultants' reports about each organization. This investigation enabled us to examine each organization's social responsibility programs in greater depth, improve the quality of our final interpretation, and triangulate the data (Beverland and Lindgreen, 2010; Strauss and Corbin, 1998; Yin, 1994). The unit of analysis is each case, so we included information from each interview and the secondary sources into a single case manuscript for each firm. In total, this process resulted in a transcript of 98 pages. 
We analyzed the cases using Eisenhardt's (1989) within-case and cross-case methods. First, we assessed the usefulness of previously developed taxonomies by allocating components of each case's social responsibility program to the various categories of the framework to assess their fit (Table 1). Second, we analyzed each case to gain a richer understanding of the processes each organization undertook to move toward social responsibility. This richer understanding prompted us to refine the taxonomy and suggest some possible paths for the further development of CSR in a Colombian context.

Each case in the study has achieved a different degree of social responsibility implementation, so we compared them to assess similarities and differences and gain a greater understanding of the processes involved. To elaborate on the theoretical categories, we employed open and axial coding procedures (Strauss and Corbin, 1998). Throughout the analysis, we tacked back and forth between literature pertaining to change and the study data and thereby developed several theoretical categories and subcategories (Spiggle, 1994).

Throughout, we have adopted various methods to improve research quality (Beverland and Lindgreen, 2010). Consistent with the recommendations of interpretive researchers (Lincoln and Guba, 1985), grounded theorists (Strauss and Corbin, 1998), and previous case-based research (Yin, 1994), we apply criteria of credibility, transferability, dependability, confirmability, integrity, fit, understanding, generality, and control to improve the reliability of the findings. In particular, experts helped us select the cases; we each provided an independent interpretation of the findings; we conducted multiple interviews; each respondent had the opportunity to offer feedback on the initial findings; and colleagues performed independent coding of the transcripts.

\section{Discussion of Findings}

We summarize our findings by drawing particular attention to the degree of inclusiveness that we perceive in the discussion of social strategies adopted by the case organizations. We start 
by providing an overview of the findings, before discussing in greater detail what we see as a set of possible paths for further CSR developments in the Colombian context.

\section{Overview of Findings}

As depicted in Figure 2, all the organizations we examined "do something" about their social environment, and their actions are explicit; what varies is the scope of their actions, the audiences toward which those actions are directed, and their geographical influence. Organizations maintain mechanisms aimed at responding to both employees and members of their geographical communities of influence. A common strategy to attend to the needs of employees focuses on two main areas: basic education for their families and microbusiness efforts (business start-up and development) (see Table 2). Organizations consider these efforts adequate to ensure a good workforce, along with generating employment for their geographical constituencies. Both education and business start-ups also are conceived of as contributions to the country's overall development, as exemplified in Figure 2 by the extension of social strategies beyond their geographical scope. Larger organizations such as Santo Domingo Foundation, Fundación Corona, and Promigas operate at a national level, whereas most other organizations adopt strategies to benefit their local communities. Only one organization (Fedco) employs a mixed strategy in which it works both within its local community and outside it (in a specific area), though not nationally. From a development view, the problems addressed can occur almost everywhere and thus need attention in various geographical locations.

\section{[Insert Figure 2 Around Here]}

\section{Detailed Strategies: Cost, Then Diversification}

A more detailed analysis of managers' perceptions (Table 2) reveals two overlapping types of social strategies that, according to the case organizations, add value to the social environment: cost and diversification. The cost-based strategy appeals to particular segments 
or "submarkets" of the population with limited access to products or services. For example, Electrocosta and Electrocaribe offer their existing services at reduced tariffs for impoverished customers.

This type of strategy links strongly to a diversification strategy. ${ }^{\mathrm{i}}$ Alliances between organizations and third parties (e.g., educational institutions, health care providers) provide three basic services: education, healthcare, and access to credit. Organizations like Grupo Santo Domingo, Promigas, Monomeros, Intercor, and Mamonal partner with universities and local government to deliver programs and facilities to their communities of influence (Santo Domingo and Promigas do so nationally). These efforts do not focus solely on developing a business opportunity but instead offer services at minimum cost, and the partner organizations for implementing these strategies are chosen because they share some common values (i.e., in their missions or organizational cultures) with those that promote the strategy. For the interviewees, this strategy also entailed a minimum cost, which meant no extra hurdles (e.g., organizational arrangements, investments, legal proceedings) to implement it.

Strategies based on attention to needs (education, business start-ups), cost, and diversification, which could be extended to different geographical locations, suggest a form of local CSR in Colombia that tackles grassroots problems related to the country as a whole and possibly to problems of development. Having identified this form, we must determine how it fits with existing CSR literature and devise means to advance the notion. In the next section, we propose a social strategy path for CSR development.

\section{A Path for Social Strategy Development}

Prior CSR literature has proposed various dimensions or domains (social, economic, ethical, legal) that organizations can fulfill to play an active role in society (Carroll, 1999; Garriga and Melé, 2004). However, and as we discussed previously, discussion remains about the role of businesses in relation to the demands of shareholders and other stakeholders. These 
ongoing discussions often pertain to how to understand voluntary or discretionary philanthropic actions (Schwartz and Carroll, 2003), which may be individually motivated, across the spectrum of CSR forms. These actions may be considered ethically or economically driven, but businesses also may act generally to serve the interests of society as a whole.

Organizations in Latin America often fulfill needs that governments cannot or will not, such as issues of poverty, corruption, and the like; in other words, they engage in development issues (Gutierrez and Jones, 2004; Schmidheiny, 2006). Practical guidance for these issues rarely appears in CSR research (Blowfield, 2007). The case organizations cited many of these topics as basic issues to be tackled head on (e.g., education, business development) and listed other issues as openly privileged (e.g., education, poverty). A long history of philanthropic efforts in Colombia has been led by entrepreneurs and international nonprofit organizations, which seem to have contributed to a generally friendly attitude toward philanthropic efforts in the country. However, the existence of a diversification strategy, which stems from a cost strategy and entails diversification, alliances, and partnerships, indicates that our case organizations largely engage in business start-ups and development, with a focus on ensuring the delivery of services rather than democratic empowerment in decision making, for example (Gutierrez and Jones, 2004). That is, they have yet to engage in clean business development, but with their own practices, they demonstrate the error of preconceptions about corruption, child employment, sweatshops, and so on (Schmidheiny, 2006). To contribute to their social environment, the organizations build on what they already do and thus contribute to alleviating pressing problems. The favorable climate for social strategies also supports opportunities to expand on this effort, such that organizations could improve their practices with the goal of being recognized internationally for their CSR. 
Therefore, drawing on our case evidence, we propose different stages of CSR development, which constitute a path that begins with minimum CSR development built on existing practices (cost) and moves toward alliances and diversified products (locally or nationally). In this minimum stage, some organizations initiate their social strategy by giving away basic raw materials or products, with the potential to diversify (see Table 3 ). For example, Cementos Argos first gave away cement, then participated in construction programs, and finally offered enhanced benefit packages for employees. Fedco started donating its products, then moved to creating educational programs. After Corona began donating existing products (i.e., home ceramic appliances) to schools, it initiated various educational programs. Other organizations in Colombia seem to adopt a similar strategy; for example, Almacenes Exito, a supermarket chain, started donating food to schools and now funds nutritional programs for children between the ages of 0 and 3 years (Revista Dinero, 2006).

Moving along this path requires organizations to consider how best to deliver their social strategy. After the minimum stage of CSR development, they appear to proceed along one of three avenues:

1. Focusing on a particular segment, such as Argos's and Fedco's attention to "subnormal" markets.

2. Establishing alliances to deliver programs in, for example, education or health (e.g., Argos, Fedco, Intercor Mamonal).

3. Creating foundations to expand on and strengthen the portfolio of social products and services and the scope of social strategies (e.g., Monomeros, Promigas, Grupo Santo Domingo and Corona).

The third stage does not necessarily signal a move away from the other two efforts; instead, it might consolidate the independence of the organizations' social strategy. For example, 
Monomeros and Promigas reconsidered their strategy and initiated education programs first in their neighborhoods and then in local communities. Next, they established foundations. Santo Domingo Group concentrated first on existing social programs. Corona's foundation uses the business group's products and develops educational programs with communities. The missions and values of these various foundations enable them to diversify and tackle core problems in Colombian society (e.g., education, poverty, unemployment); they also have core management capabilities and structures that enable them to focus on the best use of resources and generate positive impacts.

After the third stage, as we mentioned previously, social practices that reflect current business practices suggest that organizations have a basis from which to address different dimensions of CSR, especially its corporate aspects. That is, there is an opportunity to move to the recognition stage, in which organizations can adopt various corporate practices, such as compliance with international quality and monitoring standards or codes of conduct. Furthermore, they can continue to form linkages with other organizations and associations; however, this development implies that attention shifts away from corporate issues (i.e., doing good businesses), which might contribute to development. In this regard, our findings suggest that links with international CSR entities can connect with two fronts: for-profit concepts (e.g., improving business practices, efficient business management) and nonprofit ideas (e.g., autonomous foundations). Subsequent efforts could attempt to unify organizational understanding of "clean" business practices across both fronts. Moreover, firms at this point need to address issues of mismanagement, corruption, and ethics to not only generate a positive image in their communities but also improve their international standing (Schmidheiny, 2006). As they adopt new practices and improve their existing ones, it remains to be seen if organizations can (or should) amalgamate the new practices with their own mission, vision, values, and objectives. 


\section{Concluding Remarks}

Our study suggests that in general, organizations develop a social strategy that reflects their inherent desire to do something. The development of their strategy depends on various aspects related to their core business strategies, including cost and diversification. These strategic elements resonate in principle with previously identified drivers of CSR development in Colombia and Latin America, especially with regard to the integration of CSR strategies into core business strategies (i.e., business integration; see Gutierrez and Jones, 2004). However, we also find other elements that appear to represent advanced CSR, including community involvement as a cornerstone for CSR sustainability (Peinado-Vara, 2006). Despite this apparent similarity, we find key differences between social strategies and "official” CSR theory.

First, organizations develop in-house CSR strategies to tackle issues that they deem related to CSR but that might better be referred to as development. All our case organizations attend to their employees. To benefit important stakeholders, especially employees and their local community, they provide their own products or services, education, and credit. This strategy seems driven by a desire to do something about the current situation; in Colombia, this desire has been fuelled by the private business sector. The role of private organizations, government organizations, and foundations has been shaped by the realm of the possible and immediately feasible. It would be difficult to identify unquestionably the ethical rationale behind the desire to do something, but it appears it is not just self-interested. Rather, this desire seems partly driven by the very definition of a strategy that acts on the environment and addresses the needs of stakeholders.

Second, the findings suggest that when they move out of the minimal stage of CSR development, organizations often find partners that help them extend the scope of their 
strategies and/or diversify so that they can attend to the wider needs of their communities. That is, they adopt (temporarily) a leveraged social strategy. In this regard, the combination of relevant strategies (i.e., product diversification, extension of geographical influence) appears to depend on the partners with which the organizations can identify common interests, which then enables each actor to do what it does best. Further research should work to determine if this type of transitional degree of temporality appears in other organizations in Colombia and Latin America. Achieving independence in social strategy appears to require resources (often drawn from business capabilities), planning, and, perhaps most important, time.

Third, the findings confirm some "atypical" cases, such as Electrocosta, that do not fit easily with official notions of CSR. These organizations follow the steps required to become best practices and appear in prior literature as exemplars (Peinado-Vara, 2006). Similar to Bimbo in Mexico (Gutierrez and Jones 2004), the Electrocosta case shows that it is possible to assist communities (e.g., subnormal markets), then generate opportunities for education and microbusinesses, which extend the influence of CSR to many other groups of stakeholders. Our study captures what might be called an initial stage of CSR: minimal assistance, followed by alliances and some product diversification.

Fourth, in terms of what organizations must face to gain international recognition as CSR oriented (Revista Dinero, 2006), we note that the question of what needs to be done to align existing practices with internationally and officially recognized CSR practices emerges as very important. Our findings suggest a preliminary strategic trajectory. For international recognition, we agree with Gutierrez and Jones (2004): Financial elements are only part of the definition of a CSR strategy. The trajectory we depict does not require heavy financial investments (i.e., organizations can start with a minimum investment and leverage their social impact through alliances or diversification). If desires and pressures lead organizations to 
move toward more sophisticated forms of CSR (e.g., among our case organizations, the foundations), they can do so by establishing partnerships with similar types of organizations, which provide assistance and expertise in establishing more formal structures to facilitate stakeholder interactions and governance. A key issue is the integration of these forms of CSR with the firm's current mission, vision, and corporate practices, as well as devising methods to deal with potential remaining issues, such as corruption and mismanagement.

\section{Limitations and Further Research}

Our focus on social strategy as an inherent part of business strategy suffers from some limitations. First, we have assumed that knowledge about strategy is common to all the organizations we study and that any socially oriented action derives from a strategy formulation. However, some organizations may find the strategy path unnecessary or undesirable for their efforts to engage in CSR. Second, by focusing on particular ways to strategize (i.e., value, cost, differentiation), we might have overlooked other aspects that contribute to social strategies, such as the motivations behind them. In particular, research should investigate the rationale behind the need to "do something" about a social situation. Implementing action based on such a need would require a critical organizational review, especially if not every organization or stakeholder considers it important. In this regard, research should consider how social strategies come to fruition: who defines them, how they are effectively deployed and integrated (with the main business), how they are sustained, what sort of tensions arise among stakeholders, and what impacts they have in the long term. These issues offer an interesting and ethically driven research agenda for the future.

\section{References}

Aguilera, R., Rupp, D., Williams, C., and Ganapathi, J.: 2007, 'Putting the S Back in Corporate Social Responsibility: A Multilevel Theory of Social Change in Organizations', Academy of Management Review 32(3): 836-863. 
Andriof, J. and M. McIntosh: 2001, Perspectives on Corporate Citizenship (Greenleaf Publishing, Sheffield).

Bedicks, H., and C. Arruda: 2005, 'Business Ethics and Corporate Governance in Latin America', Business and Society 44(2): 218-228.

Beverland, M.B., and A.. Lindgreen: 2010, 'What Makes a Good Case Study? A Positivist Review of Qualitative Case Research Published in Industrial Marketing Management, 1971-2006’, Industrial Marketing Management 39(1): 56-63.

Blowfield, M.: 2007, 'Reasons to be Cheerful? What We Know about CSR's Impact', Third World Quarterly 28(4), 683-695.

Bhattacharya, C.B. and S. Sen: 2004, 'Doing Better at Doing Good: When, Why, and How Consumers Respond to Corporate Social Initiatives', California Management Review 47(1), 9-24.

Brammer, S., and A. Millington: 2003, 'The Effect of Stakeholder Preferences, Organizational Structure and Industry Type on Corporate Community Involvement', Journal of Business Ethics 45(3): 213-226.

Burton, B., Farh, J.-L., and Hegarty, W.: 2000, 'A Cross-Cultural Comparison of Corporate Social Responsibility Orientation: Hong Kong vs. United States Students', Teaching Business Ethics 4(2), 151-167.

Carroll, A.: 1999, 'Corporate Social Responsibility: Evolution of a Definitional Construct', Business and Society 38(3): 268-295.

Chapple, W. and Moon, J.: 2005, 'Corporate Social Responsibility (CSR) in Asia: A SevenCountry Study of CSR', Business and Society 44(4), 415-441.

Crane, A and Matten, D.: 2007, Business Ethics, 2nd ed. (Oxford University Press, Oxford). Crane, A., D. Matten, and J. Moon: 2008, Corporations and Citizenship: Business, Responsibility and Society (Cambridge University Press, Cambridge). 
Crane, A., D. Matten, and L. Spence (Eds.): 2008, Corporate Social Responsibility: Readings and Cases in a Global Context (Routledge, Abingdon).

Dávila, C., and H.G. Samper: 1994, 'Innovative Management and Organizational Development in Latin America', The International Executive 36(6): 671-688.

de Oliveira, J.: 2006, 'Corporate Citizenship in Latin America: New Challenges for Businesses', Journal of Corporate Citizenship 21(1): 17-20.

Dunphy, D., A. Griffiths, and S. Benn: 2003, Organizational Change for Corporate Sustainability (Routledge, London).

Egri, C., and D. Ralston: 2008, 'Corporate Responsibility: A Review of International Management Research from 1998 to 2007', Journal of International Management 14(4): 319-339.

Eisenhardt, Kathleen M.: 1989. 'Building Theories from Case Study Research', Academy of Management Review 14(4), 532-550.

Fox, T.: 2004, 'Corporate Social Responsibility and Development: In Quest of an Agenda', Development 47(3), 29-36.

Garriga, E. and D. Melé: 2004, 'Corporate Social Responsibility Theories: Mapping the Territory', Journal of Business Ethics 53(1/2), 51-71.

Gutierrez, R., and A. Jones: 2004, 'Corporate Social Responsibility in Latin America: An Overview of its Characteristics and Effects on Local Communities', Workshop on Corporate Social Responsibility in the Promotion of Social Development: Experiences from Latin America and Asia. Tokyo.

Haslam, P.: 2004, The Corporate Social Responsibility System in Latin America and the Caribbean (Canadian Foundation for the Americas, Ontario, CA).

Hawkins, D.: 2006, Corporate Social Responsibility: Balancing Tomorrow's Sustainability and Today's Profitability (Palgrave, Basingstoke). 
Ibarra-Colado, E.: 2006, 'Organization Studies and Epistemic Coloniality in Latin America: Thinking Otherness from the Margins', Organization 13(4): 463-488.

Kotler, P. and N. Lee: 2005, Corporate Social Responsibility: Doing the Most Good for Your Company and Your Cause (John Wiley \& Sons, Hoboken, NJ).

Kusku, F. and Zarkada-Fraser, A.: 2004, 'An Empirical Investigation of Corporate Citizenship in Australia and Turkey', British Journal of Management 15, 57-72.

Lee, M. D. P.: 2008, 'A Review of the Theories of Corporate Social Responsibility: Its Evolutionary Path and the Road Ahead', International Journal of Management Reviews 10(1): 53-73.

Lichtenstein, D. R., M. E. Drumwright, and B. M. Braig: 2004. 'The Effect of Corporate Social Responsibility on Customer Donations to Corporate-supported Nonprofits', Journal of Marketing 68(4), 16-32.

Lincoln, Y. S. and E. Guba: 1985, Naturalistic Inquiry (Sage Publications, Beverly Hills, CA).

Lindgreen, A.: 2008. Managing Market Relationships (Gower Publishing, Ashgate, Farnham).

Lindgreen, A., Swaen, A., and Campbell, T.: 2010, 'Corporate Social Responsibility Practices in Developing and Transitional Economies: Botswana and Malawi', Journal of Business Ethics, in press.

Lindgreen, A., Swaen, V., and Johnston, W. J.: 2007, 'Corporate social responsibility: an empirical investigation of U.S. organizations', Journal of Business Ethics 85(Supplement 2), 303-323.

Maon, F., A. Lindgreen, and V. Swaen: 2008, 'Thinking of the Organization as a System: The Role of Managerial Perceptions in Developing a Corporate Social Responsibility Strategic Agenda', Systems Research and Behavioral Science 25(3): 413-426. 
Matten, D. and Moon, J.: 2008, 'Implicit' and 'Explicit' CSR: A Conceptual Framework for a Comparative Understanding of Corporate Social Responsibility', Academy of Management Review 33(2), 404-424.

McWilliams, A., D. S. Siegel, and P. M. Wright: 2006, 'Corporate Social Responsibility: Strategic Implications', Journal of Management Studies 43(1), 1-18.

Mendoza, J.M.: 2006, Innovación por lo Alto: Imaginación y Acción en la Empresa (Asesores del 2000, Santafé de Bogotá).

Ospina, A.: 2005. Las Buenas Prácticas: El Nivel Estratégico de la Responsabilidad Social Empresarial (RSE) (Centro Colombiano de Responsabilidad Empresarial [CCRE], Bogotá).

Peinado-Vara, E.: 2006, 'Corporate Social Responsibility in Latin America', Journal of Corporate Citizenship 21(3): 61-69.

Pinkston, T. S. and A. B. Carroll: 1996, 'A Retrospective Examination of CSR Orientations: Have They Changed?' Journal of Business Ethics 15(2), 199-206.

Porter, M.: 1980, The Competitive Strategy (The Free Press, New York, NY).

Prieto-Carron, M., Lund-Thomsen, P., Chan, A., Muro, A., and Bhushan, C.: 2006, 'Critical Perspectives on CSR and Development: What We Know, What We Don't Know, and What We Need to Know', International Affairs 82, 977-987.

Revista Dinero: 2006, 'Responsabilidad Social Empresarial: Los Buenos Valores Valorizan as Marcas', Revista Dinero, 58-231.

Schmidheiny, S.: 2006, 'A View of Corporate Citizenship in Latin America', Journal of Corporate Citizenship 21(1), 21-24.

Schwartz, M. and A. Carroll, A.: 2003, 'Corporate Social Responsibility: A Three-domain Approach', Business Ethics Quarterly 13(4), 503-530. 
Smith, N.C., and G. Lenssen (Eds.): 2009, Mainstreaming Corporate Responsibility (Wiley, Chichester).

Snider, J., R. P. Hill, and D. Martin: 2003, 'Corporate Social Responsibility in the 21st Century: A View from the World's Most Successful Firms', Journal of Business Ethics 48(2), 175-187.

Spiggle, Susan: 1994, 'Analysis and Interpretation of Qualitative Data in Consumer Research', Journal of Consumer Research 21(3), 491-503.

Strauss, A. and J. Corbin: 1998, Basics of Qualitative Research, 2nd ed. (Sage Publications, Newbury Park, CT).

Visser, W.: 2006, 'Revisiting Carroll's CSR Pyramid: An African Perspective', in Pedersen, E.R. and Huniche, M. (Eds.), Corporate Citizenship in Developing Countries (Copenhagen Business School Press, Copenhagen).

Vives, A.: 2006, 'Social and Environmental Responsibility in Small and Medium Enterprises in Latin America', Journal of Corporate Citizenship 21, 39-50.

Yin, R.K.: 1994, Case Study Research, Sage Publications (Thousand Oaks, CA).

Zadek, S.: 2007, The Civil Corporation: The New Economy of Corporate Citizenship (Earthscan, London). 


Corruption
Poverty
Corporate mismanagement

Figure 1. Spectrum of CSR possibilities for Latin America
Integrated business strategies

Social issues

Compliance with codes of conduct, governance, and sustainability

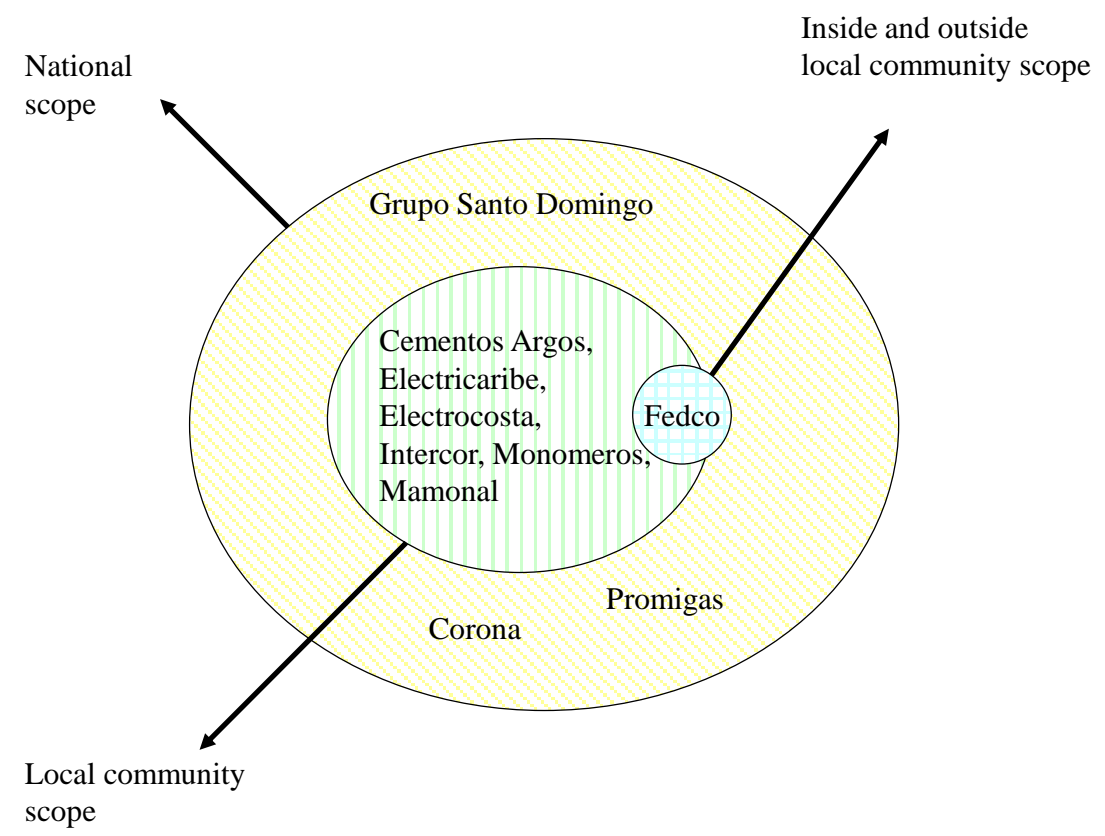

Figure 2. Geographical Scope of Social Strategies 


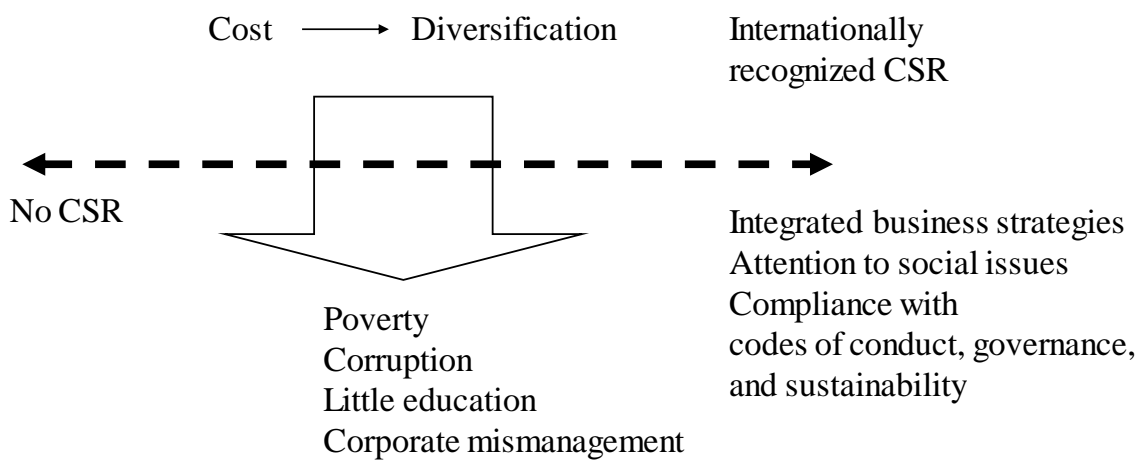

Figure 3. Spectrum of Social Strategies 
Table 1: Classification of Strategies

\begin{tabular}{|c|c|}
\hline \multicolumn{2}{|c|}{ Strategy } \\
\hline Level of Autonomy & Portfolio of Products \\
\hline Independent: & Existing products: \\
\hline$\circ \quad$ Leveraged & $\circ$ Relational \\
\hline$\circ$ Autonomous & $\circ$ General interest \\
\hline Scope: & Diversification \\
\hline ○ Employees & ○ Specialized \\
\hline o Neighborhood & ○ Diversified \\
\hline$\circ \quad$ National & \\
\hline Value & Market: \\
\hline$\circ$ Minimum cost & ○ Global \\
\hline o Differentiation & ○ Segmented \\
\hline & ○ Niche \\
\hline
\end{tabular}


Table 2: Case Information

\begin{tabular}{|c|c|c|c|c|c|}
\hline Case Organization & $\begin{array}{l}\text { Motivations for } \\
\text { Social Involvement }\end{array}$ & $\begin{array}{l}\text { Strategies for } \\
\text { implementing Social } \\
\text { Responsibility }\end{array}$ & $\begin{array}{l}\text { Pressures for and } \\
\text { Against Social } \\
\text { Responsibility }\end{array}$ & Examples & $\begin{array}{l}\text { Networks and } \\
\text { Alliances with }\end{array}$ \\
\hline Acesco & $\begin{array}{l}\text { Social problems in the } \\
\text { local community } \\
\text { (poverty, } \\
\text { unemployment) }\end{array}$ & $\begin{array}{l}\text { Locally oriented and } \\
\text { using product (real } \\
\text { state materials) }\end{array}$ & $\begin{array}{l}\text { Improve the } \\
\text { organization's image } \\
\text { in the local community }\end{array}$ & $\begin{array}{l}\text { Educational } \\
\text { programme }\end{array}$ & $\begin{array}{l}\text { Universidad Javeriana } \\
\text { (education), Promigas } \\
\text { (company) and local } \\
\text { government }\end{array}$ \\
\hline Cementos Argos & $\begin{array}{l}\text { Social problems in the } \\
\text { local community } \\
\text { (poverty, } \\
\text { unemployment) }\end{array}$ & Product: Cement & $\begin{array}{l}\text { Needs of people } \\
\text { around and the } \\
\text { organization's } \\
\text { environmental impact }\end{array}$ & $\begin{array}{l}\text { Educational } \\
\text { programme }\end{array}$ & $\begin{array}{l}\text { Promigas (company) } \\
\text { and Monomeros }\end{array}$ \\
\hline Electricaribe & $\begin{array}{l}\text { Government regulation } \\
\text { and legal business } \\
\text { requirement }\end{array}$ & $\begin{array}{l}\text { Diversification: } \\
\text { Services and financial } \\
\text { recovery }\end{array}$ & $\begin{array}{l}\text { Internal financial } \\
\text { considerations }\end{array}$ & $\begin{array}{l}\text { Entrepreneurship } \\
\text { (business start up) } \\
\text { project }\end{array}$ & No alliance \\
\hline Electrocosta & $\begin{array}{l}\text { Government regulation } \\
\text { and legal business } \\
\text { requirement }\end{array}$ & $\begin{array}{l}\text { Diversification: } \\
\text { Services and financial } \\
\text { recovery }\end{array}$ & $\begin{array}{l}\text { Internal financial } \\
\text { considerations }\end{array}$ & $\begin{array}{l}\text { Entrepreneurship } \\
\text { (business start up) } \\
\text { project }\end{array}$ & No alliance \\
\hline Fundación Corona & Own idea & $\begin{array}{l}\text { Diversification: } \\
\text { Education at National } \\
\text { level }\end{array}$ & $\begin{array}{l}\text { Social problems of } \\
\text { Colombia (poverty, } \\
\text { health, education) and } \\
\text { inefficient } \\
\text { management styles) }\end{array}$ & $\begin{array}{l}\text { Educational } \\
\text { programmes for } \\
\text { different groups }\end{array}$ & $\begin{array}{l}\text { National partnership } \\
\text { with government } \\
\text { organizations }\end{array}$ \\
\hline Fundación Mamonal & $\begin{array}{l}\text { Making a social and } \\
\text { ecological contribution } \\
\text { to the inhabitants of } \\
\text { the area }\end{array}$ & $\begin{array}{l}\text { Product/service: } \\
\text { Education in the Local } \\
\text { community }\end{array}$ & $\begin{array}{l}\text { Needs of the } \\
\text { immediate community } \\
\text { and ecosystem }\end{array}$ & $\begin{array}{l}\text { Ecological } \\
\text { management and } \\
\text { educational } \\
\text { programmes }\end{array}$ & $\begin{array}{l}\text { Universities } \\
\text { (Universidad del } \\
\text { Norte, Barranquilla) } \\
\text { and local government }\end{array}$ \\
\hline $\begin{array}{l}\text { Fundación Mario } \\
\text { Santo Domingo }\end{array}$ & $\begin{array}{l}\text { Policy requirement of } \\
\text { the Holding (Sto } \\
\text { Domingo Group }\end{array}$ & Diversification & $\begin{array}{l}\text { Social problems of } \\
\text { Colombia (education, } \\
\text { health, unemployment) }\end{array}$ & $\begin{array}{l}\text { Entrepreneurship } \\
\text { (business start up) } \\
\text { project, health service } \\
\text { provision for the } \\
\text { poorest, basic primary } \\
\text { education }\end{array}$ & $\begin{array}{l}\text { International, national } \\
\text { and government } \\
\text { organizations }\end{array}$ \\
\hline Intercor & $\begin{array}{l}\text { Having a presence in } \\
\text { the local neighborhood }\end{array}$ & Diversification & $\begin{array}{l}\text { Tensions between the } \\
\text { indigenous Wayuu } \\
\text { community and } \\
\text { employees }\end{array}$ & $\begin{array}{l}\text { Health service } \\
\text { provision for the } \\
\text { poorest, basic primary } \\
\text { education }\end{array}$ & $\begin{array}{l}\text { Universities } \\
\text { (Universidad del } \\
\text { Norte, Barranquilla) } \\
\text { and regional }\end{array}$ \\
\hline
\end{tabular}




\begin{tabular}{|c|c|c|c|c|c|}
\hline & & & & & government \\
\hline $\begin{array}{l}\text { Monómeros Colombo- } \\
\text { Venezolanos }\end{array}$ & $\begin{array}{l}\text { Having a presence in } \\
\text { the local neighborhood }\end{array}$ & Diversification & $\begin{array}{l}\text { Social problems of } \\
\text { local community } \\
\text { (education, } \\
\text { unemployment) }\end{array}$ & $\begin{array}{l}\text { Entrepreneurship } \\
\text { (business start up) } \\
\text { project, health service } \\
\text { provision for the } \\
\text { poorest }\end{array}$ & $\begin{array}{l}\text { Promigas and } \\
\text { Cementos Argos } \\
\text { (companies) }\end{array}$ \\
\hline Promigas & $\begin{array}{l}\text { Poor and limited } \\
\text { educational } \\
\text { opportunities in the } \\
\text { North Coast of } \\
\text { Colombia }\end{array}$ & $\begin{array}{l}\text { Diversification and } \\
\text { also use of CEO's } \\
\text { influence in national } \\
\text { education association }\end{array}$ & $\begin{array}{l}\text { Several communities } \\
\text { in the country next to } \\
\text { operation line }\end{array}$ & $\begin{array}{l}\text { Educational } \\
\text { programme }\end{array}$ & $\begin{array}{l}\text { Acesco (construction } \\
\text { materials consortium), } \\
\text { Instituto Merani } \\
\text { (educational } \\
\text { organization) and local } \\
\text { government }\end{array}$ \\
\hline Fedco & $\begin{array}{l}\text { Making a social } \\
\text { contribution to the } \\
\text { inhabitants of the area }\end{array}$ & $\begin{array}{l}\text { Diversification in a s } \\
\text { specific community in } \\
\text { Barranquilla }\end{array}$ & $\begin{array}{l}\text { Administrative Vice- } \\
\text { President }\end{array}$ & $\begin{array}{l}\text { Business start up in } \\
\text { beauty advice and } \\
\text { beauty products }\end{array}$ & No \\
\hline
\end{tabular}


Table 3: Summary of Qualitative Case Studies

\begin{tabular}{|c|c|c|c|}
\hline $\begin{array}{l}\text { Research Topics Emerging from the } \\
\text { Interviews }\end{array}$ & Case Organizations & $\begin{array}{l}\text { Region of Social Responsibility } \\
\text { Influence and Type of Industry }\end{array}$ & Sources of Information \\
\hline Social strategy, social services, history & Cementos Argos & $\begin{array}{l}\text { Barranquilla city } \\
\text { Cement }\end{array}$ & Vice-President and Social Manager \\
\hline Social model and its impacts & Electricaribe & $\begin{array}{l}\text { Barranquilla city } \\
\text { Electricity }\end{array}$ & Social Manager \\
\hline Social model and its impacts & Electrocosta & $\begin{array}{l}\text { Cartagena city } \\
\text { Electricity }\end{array}$ & Social Manager \\
\hline $\begin{array}{l}\text { History, organization's social strategy, role } \\
\text { played nationally in Colombia }\end{array}$ & Fundación Corona & $\begin{array}{l}\text { National } \\
\text { Ceramics }\end{array}$ & President \\
\hline $\begin{array}{l}\text { Social services, coverage, structure and } \\
\text { processes to support service delivery }\end{array}$ & Fundación Mamonal & $\begin{array}{l}\text { Cartagena city } \\
\text { Autonomous non for profit } \\
\text { Foundation }\end{array}$ & President \\
\hline $\begin{array}{l}\text { Social services, national coverage, finance, } \\
\text { structure to support service delivery }\end{array}$ & $\begin{array}{l}\text { Fundación Mario Santo } \\
\text { Domingo }\end{array}$ & $\begin{array}{l}\text { National } \\
\text { Autonomous non for profit } \\
\text { Foundation }\end{array}$ & President \\
\hline $\begin{array}{l}\text { Social stakeholders, community services, } \\
\text { experience of social responsibility }\end{array}$ & Intercor & $\begin{array}{l}\text { Barranquilla city } \\
\text { Carbon/coal exploitation }\end{array}$ & Communications Manager \\
\hline $\begin{array}{l}\text { Social stakeholders, social strategy, financial } \\
\text { schemes and structure of strategy. }\end{array}$ & $\begin{array}{l}\text { Monómeros Colombo- } \\
\text { Venezolanos }\end{array}$ & $\begin{array}{l}\text { Barranquilla city } \\
\text { Autonomous non for profit } \\
\text { Foundation }\end{array}$ & General Foundation Manager \\
\hline $\begin{array}{l}\text { Social stakeholders, social strategy, processes } \\
\text { to support strategy implementation }\end{array}$ & Promigas & $\begin{array}{l}\text { Barranquilla city } \\
\text { Natural Gas Provision }\end{array}$ & General Foundation manager \\
\hline $\begin{array}{l}\text { Social stakeholder, social services derived } \\
\text { from initial engagement. }\end{array}$ & Fedco & $\begin{array}{l}\text { Barranquilla city/National } \\
\text { Mixed products chain (household, } \\
\text { appliances, beauty) }\end{array}$ & Administrative Manager \\
\hline
\end{tabular}


${ }^{\mathrm{i}}$ For Electrocosta and Electrocaribe, the products relate to the core business of the organizations. For example, debt collection and sales agencies help electricity customers legally use and pay for their service. These agencies are not owned by Electrocosta or Electrocaribe but rather by employees and shareholders. 